\title{
Prevalence of Argulus indicus, histopathology and hematological properties of infected wild fish in Lake Towuti, Indonesia
}

\author{
AMRIANA ${ }^{1}$, DWI KESUMA SARI ${ }^{2}$, SRIWULAN ${ }^{1}$, HILAL ANSHARY ${ }^{1, \boldsymbol{v}}$ \\ ${ }^{1}$ Department of Fisheries Science, Faculty of Marine Science and Fisheries, Universitas Hasanuddin. J1. Perintis Kemerdekaan Km. 10, Tamalanrea, \\ Makassar 90245, South Sulawesi, Indonesia. Tel./fax.: +62-411-586025, ^email: hilalanshary@unhas.ac.id \\ ${ }^{2}$ Department of Veterinary Medicine, Faculty of Medicine, Universitas Hasanuddin. Jl. Perintis Kemerdekaan Km. 10, Tamalanrea, Makassar 90245, \\ South Sulawesi, Indonesia
}

Manuscript received: 21 May 2021. Revision accepted: 30 July 2021

\begin{abstract}
Amriana, Sari DK, Sriwulan, Anshary H. 2021. Prevalence of Argulus indicus, histopathology and hematological properties of infected wild fish in Lake Towuti, Indonesia. Biodiversitas 22: 3578-3584. Parasites are disease agents that can threaten the health and survival of wild fish as individuals and at a population level. This study aimed to improve knowledge on the prevalence of Argulus indicus, infestation rates and the pathological effects of parasite infestation on hosts as well as hematological properties of infected fish. This study can inform future studies on the prevention and control of the cases of Argulus indicus infestation. Fish from Lake Towuti $\left(2^{0}\right.$ $45^{\prime} 0^{\prime \prime} \mathrm{S}, 121^{0} 30^{\prime} 0^{\prime \prime}$ E) were caught from February to May 2019 using traps and gill nets. The total of 373 specimens obtained comprised 102 climbing perch (Anabas testudineus), 74 three-spot cichlids (Cichlasoma trimaculatum), 84 Nile tilapia (Oreochromis niloticus), and 113 striped snakeheads (Channa striata). The prevalence, mean intensity and abundance of $A$. indicus were highest in $C$. striata with a prevalence of $81 \%$, mean intensity of 5.17 parasites/fish and abundance of 4.06 parasites/fish. The lowest parasite infection level was seen in C. trimaculatum with a prevalence of $4.1 \%$, mean intensity 1.66 and mean abundance of 0.06 . Histological analysis showed inflammatory responses in the skin of snakeheads (hemorrhage, increased spread of melanomacrophage and leukocyte cells), melanomacrophage and the spread of leukocyte cells were observed in climbing perch. In contrast, melanomacrophage was often observed in tilapia and trimac cichlid. Blood imaging analysis showed significant differences $(\mathrm{P}<0.05)$ in the number of leukocytes and percentage of monocyte cells between uninfested fish and those infested with A. indicus.
\end{abstract}

Keywords: Fish blood, infestation rate, parasitism, South Sulawesi, skin inflammation

\section{INTRODUCTION}

Lake Towuti is part of the Malili ancient lake complex formed through tectonic activity, with an area of just over 50000 hectares and a depth of more than $200 \mathrm{~m}$ (Nasution et al. 2015). Lake Towuti provides valuable services to the local community, including fresh water and electricity generation, while the aquatic biodiversity supports livelihoods based on ecotourism and fishing. Fishes reported from Lake Towuti include endemic species and introduced species, several of which are fished to provide food or as a source of broodstock for freshwater aquaculture around the lake. The size of Lake Towuti and the abundance of fish with economic value can positively impact local incomes from capture fisheries and aquaculture. However, the disease is a threat to wild fish populations, and of course, can also affect the supply of wild broodstock for aquaculture. Parasites are disease agents that can infect both wild and farmed fish (Alsarakibi et al. 2014). Parasitic infections are common in fish, especially in wild fish populations from various aquatic environments where the ecological requirements are met for both the host organism and parasite transmission (McPherson et al. 2012).

Fish lice of the genus Argulus comprise ectoparasites reported to infect fish in the wild and aquaculture, causing epidemics in many regions worldwide (Alsarakibi et al.
2012). They can adapt to environmental change to survive even in extreme conditions (Alsarakibi et al. 2014). Argulus can attach to the body of a fish using a stylet and sucker, extracting nutrients from host blood through a proboscis; this feeding activity can decrease the number of red blood cells and lower hematocrit levels, causing anemia in the host Argulus can also cause the formation of wounds, stimulating increased white blood cell production in the fish (Walker et al. 2011). Histologically, Argulus infestation can also cause pathological changes and damage to the skin of the fish. Parida et al. (2018) report an inflammatory reaction in the skin of Labeo rohita infested with Argulus siamensis. The formation of wounds on the skin of the fish can directly reduce endurance and interfere with osmoregulation mechanisms, and can increase the susceptibility of fish to fungal, bacterial and viral diseases (Kumar et al. 2016).

Argulus infestation is rarely reported to be the leading cause of host death; however, it does cause the host to be more susceptible to pathogenic infections, and there are several reports of fish mortality due to severe Argulus infestation (Pekmezci et al. 2011). Infestations by several Argulus species have been reported in Indonesia, one of which is Argulus indicus, first discovered in Indonesia in 1892 (Weber 1892). However, there have been no further reports of $A$. indicus infestation in Indonesia since then, even though $A$. indicus infestations have been reported 
from many regions worldwide (Neethling and AvenantOldewage 2016; Sriwongpuk 2020). The cases of $A$. indicus infestation in Indonesia are still very minimal, with no recent reports from aquaculture facilities or in the wild. However, the haplotype of this species was first obtained from Indonesia (Weber 1892). This indicates that there is a high probability of $A$. indicus spread across various regions in Indonesia, requiring further research to investigate the distribution of $A$. indicus within Indonesia. This study aimed to improve knowledge regarding the prevalence of A. indicus, the rate of infestation and the pathological effects of this infestation on the host. This information can inform future in-depth studies on cases of $A$. indicus infestation.

\section{MATERIALS AND METHODS}

\section{Ethics statement}

This research was conducted with the approval of the Hasanuddin University Health Research Ethics Committee for the use of experimental animals in research (Protocol No. 13720093017). All stages in this research followed the Animal Ethics Guidelines issued by the Ministry of Health of the Republic of Indonesia.

\section{Study site and sample collection}

Fish were collected from Lake Towuti $\left(2^{\circ} 45^{\prime} 0^{\prime \prime} \mathrm{S}\right.$, $121^{\circ} 30^{\prime} 0^{\prime \prime}$ E, Figure 1) from February to May 2019 using traps and gill nets. The total of 373 fish used in this study comprised 102 climbing perch (Anabas testudineus), 74 three-spot cichlids (Cichlasoma trimaculatum), 84 Nile tilapia (Oreochromis niloticus), and 113 striped snakeheads (Channa striata). Each fish was measured (total length in $\mathrm{cm}$ ) and weighed $(\mathrm{g})$. The body surface, fins, head, and gills of each fish were examined for parasites. Each parasite was removed from the body of the fish using a pair of tweezers which was rinsed in $70 \%$ alcohol between fish. Then, the samples were taken to the Fish.

Parasite and Disease Laboratory of Universitas Hasanuddin in Makassar, Indonesia. Species identification of $A$. indicus based on morphological and genetic analysis according to the previous research of Amriana et al. (2021).

\section{Histology}

Fish infected with $A$. indicus were anesthetized before dissection to remove the skin from each Argulus attachment site. Each tissue sample was placed in a sample bottle filled with a fixative solution (10\% neutral formalin buffer) and washed using $70 \%$ alcohol. The tissue sample was dehydrated through the graded alcohol (70-100\%), cleaned by xylol, impregnated using paraffin and xylol, and embedded in paraffin. The skin sections were cut with a thickness of 3-5 $\mu \mathrm{m}$, deparaffinized, rehydrated, and stained using hematoxylin-eosin (Parida et al. 2018).

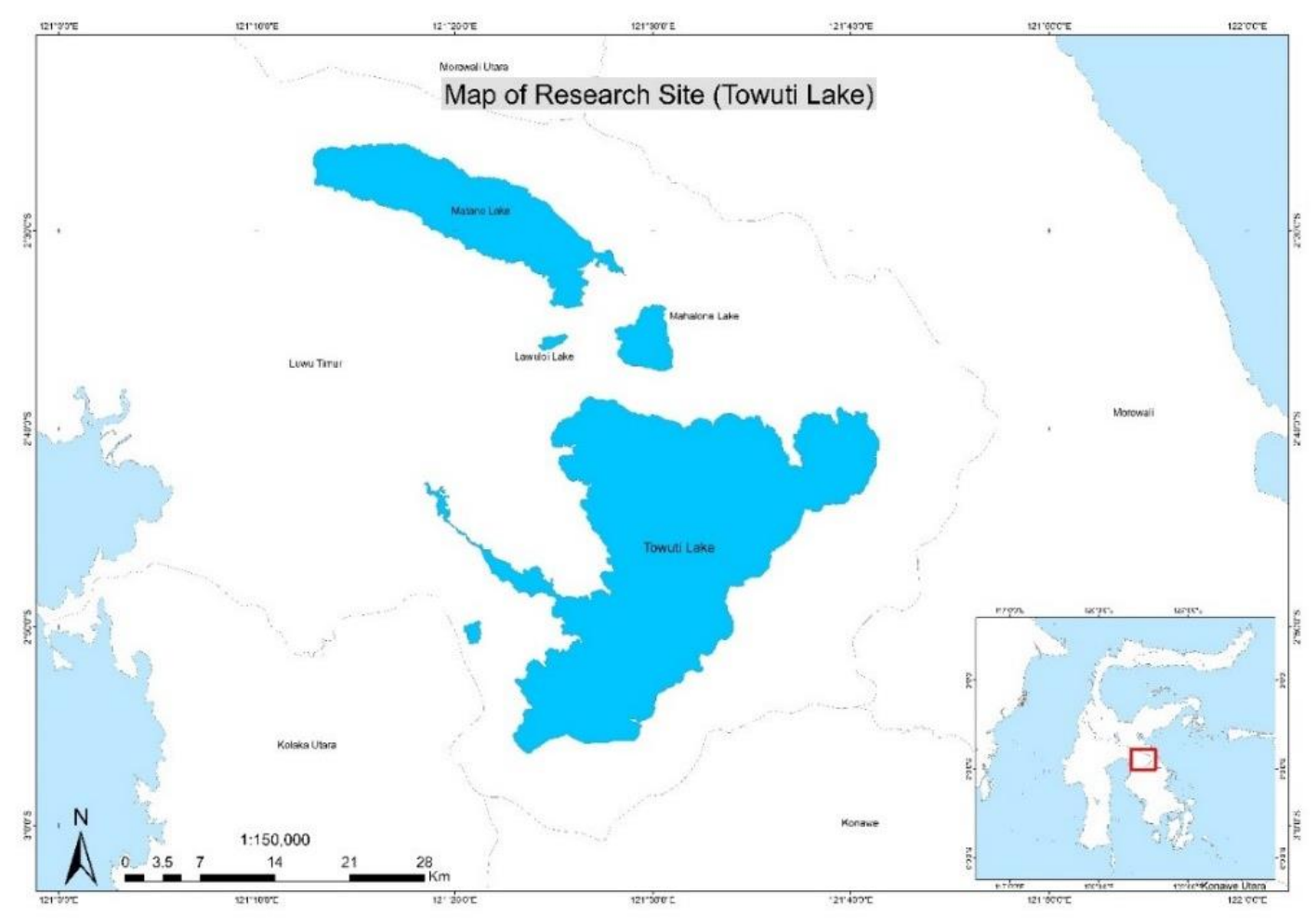

Figure 1. Lake Towuti in Luwu Timur District, South Sulawesi Province, Indonesia 


\section{Blood collection}

For each of the species found to be infested with $A$. indicus, three infested and three non-infested specimens were anesthetized using clove oil at a concentration of 1 $\mathrm{mL} / \mathrm{L}$. Blood was then drawn from each anesthetized specimen using a $1 \mathrm{~mL}$ Terumo medical syringe. The needle was inserted into the muscle along the lateral line behind the anal fin until it reached the spine. The syringe plunger was then slowly withdrawn until the syringe was filled with blood. The blood obtained was placed in a vacuum tube containing an anticoagulant and a paper label. Blood samples were analyzed to determine the number of erythrocytes and leukocytes as well as to observe leukocyte cell differentiation, according to the methods of Blaxhall and Daisley (1973).

\section{Erythrocyte count}

The number of erythrocytes was determined by aspirating blood into a special pipette for measuring the number of red blood cells, with red stirring grains in it until the scale of 1 was reached. The blood was then mixed with Hayem's solution to the 101 marks on the pipette. The pipette was shaken by making a figure of eight movements to ensure the contents were thoroughly mixed. The first two drops of the solution were discarded before transferring the liquid to a hemocytometer and covering it with a glass cover. Counts were performed under a binocular microscope with a magnification of $40 \mathrm{X}$. The number of erythrocytes were counted in 10 small compartments in the hemocytometer and converted to obtain the number of blood cells per mm3. Erythrocyte count equation:

Number of Red Blood Cells $=$ No. cells counted $\mathrm{x}$ dilution factor/area counted $\left(\mathrm{mm}^{2}\right) \mathrm{x}$ depth (Blaxhall and Daisley 1973).

\section{Leukocyte count}

The number of leucocytes was determined by aspirating blood into a special pipette until the 0.5 marks was reached. The blood was then mixed with Turk's solution to the 11 marks on the pipette. The pipette was shaken by making a figure of eight movements to ensure thorough mixing. The first two drops of the solution were discarded before transferring the liquid to a hemocytometer and covering it with a glass cover. Capillary action was used to transfer the liquid to the counting chamber. The number of leukocytes was counted in 5 out of the 16 small compartments in the hemocytometer and converted to obtain the number of cells per mm3. Leucocyte count equation:

Number of White Blood Cells $=$ No. cells counted $\mathrm{x}$ dilution factor/area counted $\left(\mathrm{mm}^{2}\right) \mathrm{x}$ depth (Blaxhall and Daisley 1973).

\section{Blood smear preparations (Differential leukocyte observation)}

Two glass slides were used to make blood smears (slide A and slide B). A drop of blood was placed on slide A, and slide B was placed over the drop of blood at an angle of $45^{\circ}$ s to slide A. Slide B was then moved to the right and then to the left quickly and steadily to obtain a thin film of blood on each slide. The slides were then air-dried before being placed in methanol for 5 minutes, and then placed in Giemsa dye for 20 minutes. The slides were washed with running water for 5 minutes and dried. The dry preparations were observed using a microscope at 100x magnification. The leukocyte differential count was counted up to 100 cells and the percentage of each type (lymphocyte, monocyte, eosinophil, basophil, and neutrophil) was counted.

Proportion of a leukocyte cell type $=$ number of the leukocyte cell type x $100 \%$ / Total number of leukocytes (Blaxhall and Daisley 1973).

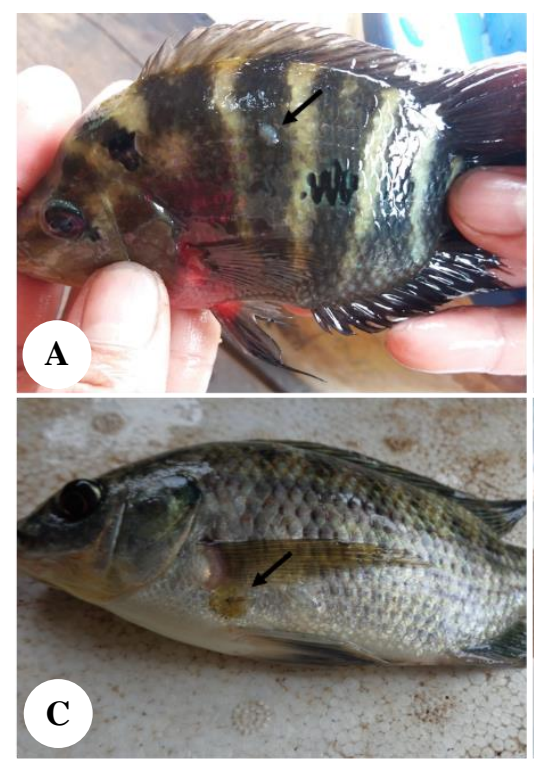

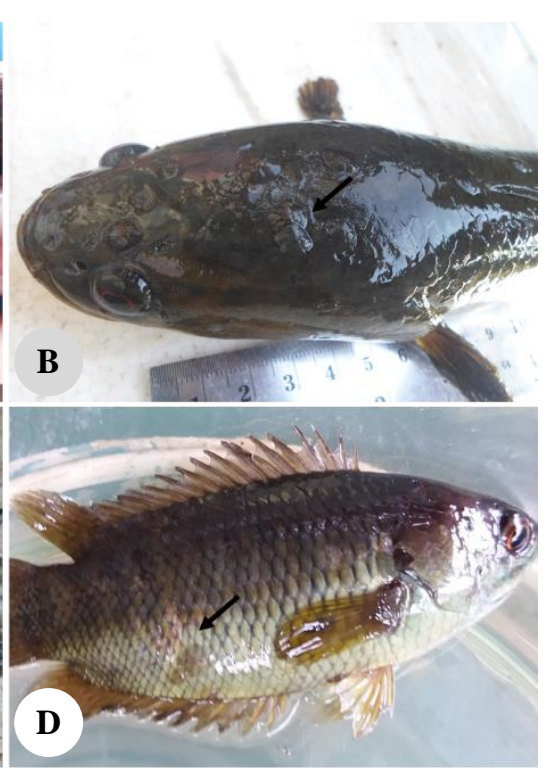

Figure 2. Argulus indicus infestation on freshwater fish in Lake Towuti District, South Sulawesi Province, Indonesia: A. Cichlasoma trimaculatum; B. Channa striata; C. Oreochromis niloticus; D. Anabas testudineus. Arrow showed location of A. indicus on host body 


\section{Data analysis}

Prevalence, mean intensity and abundance were calculated according to the methods of Bush et al. (1997) tabulated. Histological observations were analyzed descriptively while the T-test at the $95 \%$ confidence level $(\mathrm{P}<0.05)$ was used to evaluate the significance of differences in hematological parameters between infested and non-infested fish.

\section{RESULTS AND DISCUSSION}

\section{Results}

The prevalence of $A$. indicus infestation in 373 fish from Lake Towuti was observed in four species of fish (Figure 2). These species were the three-spot cichlid $C$. trimaculatum (Figure 1A, $\mathrm{n}=74)$ ); the striped snakehead C. striata (Figure $1 \mathrm{~B}, \mathrm{n}=113$.); the Nile tilapia Oreochromis niloticus (Figure 1C, $\mathrm{n}=84$ ); and the climbing perch A. testudineus (Figure 1D, $\mathrm{n}=102$ ). The prevalence and mean intensity of infestation as well as the mean abundance of $A$. indicus varied between these species, being highest in $C$. striata with $81 \%$ prevalence, mean intensity of $5.71 \pm 1.02$ and mean abundance of $4.06 \pm 0.81$. Whereas, the lowest infestation was found on $C$. trimaculatum with $4.1 \%$ prevalence, mean intensity of $1.66 \pm 0.66$ and mean abundance of $0.06 \pm 0.04$ (Table 1)

The histopathological analysis revealed inflammatory responses in the skin of infested striped snakehead, climbing perch, tilapia specimens, and three spot cichlids (Figure 3). Histologically, there was increasing in melanomacrophage and hemorrhage, and sparse distribution of leukocytes as mild inflammatory reaction was observed in epidermal layer of $C$. striata (Figure 3.A). The skin of $A$. testudineus revealed leukocyte distribution and increasing hemorrhage in dermal layer (Figure 3B). Whereas, $O$. niloticus and $C$. trimaculatum show melanomacrophage dermal layer (Figure 3.C-D). The histologic change indicates the inflammation reaction to attachment of $A$. indicus in skin fish. Specifically, $C$. striata, as the high infestation of $A$. indicus, show mild inflammation to parasite attachment in the skin and low inflammation on C. trimaculatum as the low infestation.

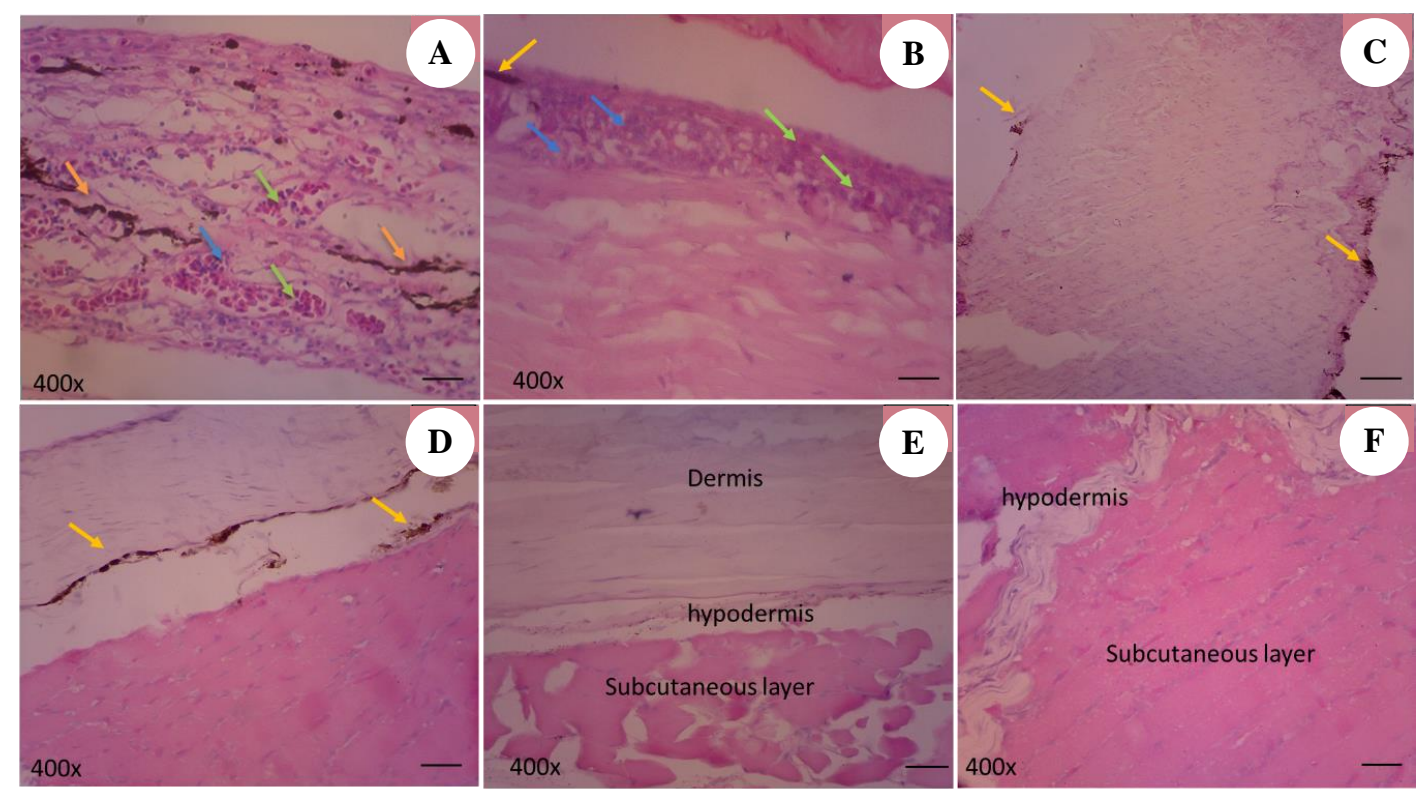

Figure 3. Histology of fish skin infested with Argulus indicus (A-D) and normal skin (E-F). Blue arrows: Inflammation; Green arrows: Hemorrhage; Orange arrows: Melanomacrophages. Bar: $100 \mu \mathrm{m}$. A. Increased number of melanomacrophages in epidermis and dermis, inflammatory and hemorrhagic cells in the epidermis of C. striata; B. Haemorrhage and spread of inflammatory cells (leukocytes) in the dermis of Anabas testudineus; C. Melanomacrophages in the dermis of Oreochromis niloticus; D. Melanomacrophages in dermal layer of Cichlasoma trimaculatum; E-F. The Normal skin of O. niloticus and C. trimaculatum

Table 1. Prevalence, mean intensity and abundance of Argulus indicus in freshwater fish from Lake Towuti, South Sulawesi, Indonesia

\begin{tabular}{|c|c|c|c|c|c|c|}
\hline Host species & $\sum$ Fish examined & $\sum$ Fish infected & $\sum$ Parasites & $\begin{array}{c}\text { Prevalence } \\
(\%)\end{array}$ & $\begin{array}{l}\text { Mean intensity } \\
(X \pm S D)\end{array}$ & $\begin{array}{c}\text { Mean abundance } \\
(\mathrm{X} \pm \mathrm{SD})\end{array}$ \\
\hline Anabas testudineus & 102 & 49 & 87 & $48 \%$ & $1.78 \pm 0.12$ & $0.85 \pm 0.18$ \\
\hline Cichlasoma trimaculatum & 74 & 3 & 5 & $4.1 \%$ & $1.66 \pm 0.66$ & $0.06 \pm 0.04$ \\
\hline Oreochromis niloticus & 84 & 4 & 7 & $4.7 \%$ & $1.75 \pm 0.40$ & $0.08 \pm 0,04$ \\
\hline Channa striata & 113 & 91 & 520 & $81 \%$ & $5.71 \pm 1.02$ & $4.06 \pm 0.81$ \\
\hline
\end{tabular}


Table 2. Blood parameters of A. indicus infested and non-infested fish from Lake Towuti, South Sulawesi, Indonesia

\begin{tabular}{|c|c|c|c|c|c|c|c|c|}
\hline Species & Hea & $\begin{array}{c}\text { Erythrocyte } \\
(\times 109 \text { cells } / \mathrm{mL})\end{array}$ & $\begin{array}{c}\text { Leukocyte } \\
(\times 106 \text { cells } / \mathrm{mL})\end{array}$ & $\begin{array}{c}\text { Lymphocyte } \\
(\%)\end{array}$ & $\begin{array}{c}\text { Monocyte } \\
(\%)\end{array}$ & $\begin{array}{c}\text { Eosinophil } \\
(\%)\end{array}$ & $\begin{array}{c}\text { Basophil } \\
(\%)\end{array}$ & $\begin{array}{c}\text { Neutrophil } \\
(\%)\end{array}$ \\
\hline \multirow[t]{2}{*}{ A. testudineus } & Not infested & $2.35 \pm 0.08^{\mathrm{ns}}$ & $2,82 \pm 0.28^{\mathrm{a}}$ & $67.00 \pm 2.00^{\mathrm{a}}$ & $14.67 \pm 1.53^{\mathrm{a}}$ & $5.67 \pm 0.58^{\mathrm{ns}}$ & $6.00 \pm 1.73^{\mathrm{ns}}$ & $6.67 \pm 2.08^{\mathrm{ns}}$ \\
\hline & Infested & $1.75 \pm 0.38^{\mathrm{ns}}$ & $4.98 \pm 0.44^{\mathrm{b}}$ & $55.00 \pm 2.00^{\mathrm{b}}$ & $30.00 \pm 2.00^{\mathrm{b}}$ & $4.00 \pm 1.00^{\mathrm{ns}}$ & $6.33 \pm 1.53^{\mathrm{ns}}$ & $4.67 \pm 1.53^{\mathrm{ns}}$ \\
\hline \multirow[t]{2}{*}{ O. niloticus } & Not infested & $2.20 \pm 0.03^{\mathrm{a}}$ & $2.66 \pm 0.13^{\mathrm{a}}$ & $68.70 \pm 2.08^{\mathrm{a}}$ & $14.00 \pm 2.00^{\mathrm{a}}$ & $6.33 \pm 1.15^{\mathrm{ns}}$ & $5.67 \pm 1.53^{\mathrm{ns}}$ & $5.33 \pm 1.53^{\mathrm{ns}}$ \\
\hline & Infested & $1.31 \pm 0.33^{\mathrm{b}}$ & $5.53 \pm 0.20^{\mathrm{b}}$ & $62.67 \pm 2.53^{b}$ & $22.00 \pm 4.58^{b}$ & $4.67 \pm 2.52^{\mathrm{ns}}$ & $6.00 \pm 3.61^{\mathrm{ns}}$ & $4.67 \pm 2.58^{\mathrm{ns}}$ \\
\hline \multirow[t]{2}{*}{ C. trimaculatum } & Not infested & $2.27 \pm 0.11^{\mathrm{a}}$ & $2.92 \pm 0.15^{\mathrm{a}}$ & $70.30 \pm 1.53^{\mathrm{a}}$ & $13.70 \pm 1.53^{\mathrm{a}}$ & $6.67 \pm 1.15^{\mathrm{a}}$ & $4.67 \pm 1.15^{\mathrm{ns}}$ & $4.67 \pm 1.15^{\mathrm{ns}}$ \\
\hline & Infested & $1.20 \pm 0.11^{\mathrm{b}}$ & $5.83 \pm 1.05^{\mathrm{b}}$ & $64.00 \pm 1.00^{\mathrm{b}}$ & $23.67 \pm 3.21^{\mathrm{b}}$ & $3.33 \pm 0.58^{b}$ & $6.00 \pm 2.08^{\mathrm{ns}}$ & $3.00 \pm 0.58^{\mathrm{ns}}$ \\
\hline \multirow[t]{2}{*}{ C. striata } & Not infested & $3.01 \pm 0.31^{\mathrm{ns}}$ & $3.33 \pm 0.11^{\mathrm{a}}$ & $69.33 \pm 2.08^{a}$ & $18.00 \pm 2.00^{\mathrm{a}}$ & $4.00 \pm 1.00^{\mathrm{ns}}$ & $5.67 \pm 0.58^{a}$ & $3.00 \pm 1.00^{\mathrm{a}}$ \\
\hline & Infested & $5.96 \pm 0.61^{\mathrm{ns}}$ & $7.48 \pm 0.08^{b}$ & $47.33 \pm 2.08^{b}$ & $31.33 \pm 2.31^{\mathrm{b}}$ & $6.00 \pm 1.00^{\mathrm{ns}}$ & $8.33 \pm 1.53^{b}$ & $7.00 \pm 1.00^{\mathrm{b}}$ \\
\hline
\end{tabular}

Note: ns: not significant $(\mathrm{P}>0.05)$; The mean values in columns with different superscripts indicate the significantly different $(\mathrm{P}<0.05)$

The fish blood sample analysis (Table 2) showed a significant difference in hematological parameters $(\mathrm{P}<0.05)$ between $A$. indicus infested fish and non-infested fish of the same species. Parasitized $C$. striata showed a significant increase $(\mathrm{P}<0.05)$ in the total of leukocytes and percentage of monocytes, basophils, and neutrophils. In contrast, the percentage of lymphocyte cell decreased compared to the unparasitized fish of the same species. $O$. niloticus and $C$. trimaculatum revealed a significant increase $(\mathrm{P}<0.05)$ in the total of leukocyte and monocytes percentage and decrease $(\mathrm{P}<0.05)$ in the lymphocyte percentage between infested fish and uninfested fish (Table 2). Whereas parasitized A. testudineus showed significant hematological value in the total of Leukocyte and Monocyte percentage and decrease in the lymphocyte percentage $(\mathrm{P}<0.05)$.

\section{Discussion}

In this study, all four fish species obtained from Lake Towuti were infested with $A$. indicus. The highest infestation level was in striped snakeheads and the lowest in three spot cichlids. This is consonant with the general perception that the fish most likely to be infected with $A$. indicus are those often found in the lower region of the water column and are less active, such as striped snakeheads and climbing perch. This is related to the strategy of A. indicus in looking for the closest host they can find, so that striped snakeheads and climbing perch have a higher probability of encountering A. indicus than tilapias or cichlids which tend to remain closer to the water surface and swim more actively (Stewart et al. 2017).

Parasitic species often exhibit a heterogeneous infestation pattern and are highly dispersed in host populations. Argulus fish lice have developed ways to optimize transmission from one fish to another. Their ability to detect visual, physical and chemical cues connected to the host can lead to rapid host discovery and enhance the potential for host infestation (Mikheev et al. 2015). Argulus need a host to survive so they have developed various tactics to be able to infest hosts. In the metanauplius stage, Argulus with incompletely developed organs will only wait near the substrate until a fish moves close to them, and then they will immediately move quickly to attach to the host's body (Mikheev et al. 2007). This is what causes Argulus metanauplii to infest more heavily those fish that are often found on or close to the substrate. Adult Argulus can swim quite fast to find a host, but they cannot maintain speed over long distances; in order to conserve energy, they will tend to attach themselves to the first potential host they encounter, making less active fish the most likely and easiest hosts for them to infest (Mikheev et al. 2015). Argulus can also manipulate the behavior of host fish to increase transmission effectiveness, while the complex Argulus life cycle that exploits several consecutive host species during different life stages is another way to increase the success of transmission (Stewart et al. 2018).

Argulus parasite infestations cause direct damage to the skin of the host fish through attachment and feeding mechanisms (Walker et al. 2011). Skin damage results from the mechanical action of maxillary suction by adult lice and the hooks or spines of the larval and juvenile stages as well as their sharp mandibles (Stewart et al. 2017). In addition, damage can occur due to various toxins or digestive enzymes secreted through the pre-oral stylet and labial spines (Walker et al. 2011). Skin infections are characterized by an inflammatory response at the site of attachment and erosion due to feeding by the parasites as well as the infiltration of inflammatory cells into the affected tissue (Parida et al. 2018).

The skin is the main target organ during ectoparasitic infection and local or systemic inflammation is a factor that regulates susceptibility or resistance to infection, and a large number of host molecules involved in immunity modulate this inflammatory response or process either directly or indirectly (Kar et al. 2016). Previously reports on host preference in Argulus siamensis, indicate that Labeo rohita depends on the degree of inflammatory response induced by parasitic activity (Kar et al. 2013). This study investigated the histopathological changes in the skin of wild C. striata, A. testudineus, C. trimaculatum, and $O$. niloticus due to the attachment of the parasite $A$. indicus. Tissue damage was visible on the skin of $C$. striata and $O$. niloticus. Leukocyte cells were widespread on the skin of C. striata infested with Argulus, indicating an inflammatory response, with hemorrhaging also present and accompanied by the spread of melanomacrophage. In C. trimaculatum only melanomacrophage was observed on the skin at the site of Argulus attachment. This difference in symptom severity is in line with the level of parasite infestation which was highest in $C$ striata and lowest in $C$. trimaculatum. 
Parasitic infestation generally causes local feeding and adhesion damage, especially when infection rates in individual hosts are very high. These areas of damage can facilitate the entry and development of secondary bacterial, fungal and viral infections (Kumar et al. 2016). Hosts can generally tolerate low-grade skin infections and are able to repair damage caused by low numbers of parasites relatively quickly. In severe infestations, however, the host cannot create an effective defense against the parasite; thus, the direct and secondary damage tend to become more intense. Inflammation, bleeding, and ulceration associated with attachment and feeding by parasites occur (Walker et al. 2011). Histologically, the act of feeding by ectoparasites can be seen to disrupt the dermal and sub-dermal tissues including muscles (Parida et al. 2018). The histological observations made in this study are consonant with these general findings.

Fish parasites can cause blood disorders including anemia, leucocytosis, and thrombocytopenia, while Argulus parasite infestations can cause stress reactions with behavioral and physiological responses in host fish (Rocha et al. 2018). For example, Ali et al. (2010) demonstrated anemic conditions in infested fish, with a decrease in the number of erythrocytes and hematocrits in host blood due to parasite feeding activity as well as failure of host osmoregulation due to skin lesions. However, the hematocrit and erythrocyte counts can also be increased with the release of stored blood cells from the spleen, loss of plasma, or by swelling of red blood cells as a stress response in Argulus-infected fish (Jones and Grutter 2005). The analysis of blood from A. indicus-infested and noninfested fish showed significant differences between the two groups (Table 2). Argulus infestation had a significant effect on the number of leukocyte cells and the percentage of monocyte cells in all observed fish species $(\mathrm{P}<0.05)$, while only $C$. trimaculatum and $O$. niloticus had significant differences in erythrocyte cell count. Increased percentages of basophil and neutrophil cells were also observed in $C$. striata, the fish species with the highest parasite attachment intensity. The study of Panjvini et al. (2016) also shows an increase in WBC in fish infected with the parasite. The increasing leukocyte count can indicate the defense mechanism and response of cellular immune mechanisms against parasites. Argulus infested fish have also shown an increase in monocyte cells (Tavares-Dias and De Moraes 2007). Monocytes are the main phagocytes in fish; during the infection-fighting process, monocytes will migrate from blood vessels to inflammatory foci (Esteban et al. 2015). In addition to monocytes, neutrophils are also involved in the defense of fish against parasites. Hematological changes may be related to physiological characteristics as well as disease or condition of the fish. In addition, in the hostparasite relationship, the severity of health changes may be related to the mechanism of attachment of the parasite, its life cycle, and in particular, the number of parasites (Fazio 2019).

Our results confirmed that At least four species of fish were found to be infested with $A$. indicus: the climbing perch (A. testudineus), three spot cichlid (C. trimaculatum), Nile tilapia ( $O$. niloticus), and striped snakehead $(C$. striata). The most severely infested was the striped snakehead, as the behavior patterns of this fish and $A$. indicus infestation tactics result in a high probability of interaction between the host and parasite species. High levels of infestation increase the inflammatory response, with symptoms observed in fish skin, including melanomacrophage, the spread of leukocyte cells, and hemorrhaging. Hematological parameters also showed significant differences between infested and non-infested fish, in particular an increase in the number of leukocyte cells and the percentage of monocyte cells in infested fish, which indicates an inflammatory response to $A$. indicus infestation in fish.

\section{ACKNOWLEDGEMENTS}

This research was funded by the Ministry for Research, Technology and Higher Education of the Republic of Indonesia under the Master to Doctor Scheme for Outstanding Bachelors (Grant No. 1739/UN4.21/PL.01.10/ 2019). The authors thank Saipul Safaruddin for assistance in obtaining fish samples from Lake Towuti, Indonesia and the staff of the Fish Parasite and Disease Laboratory of the Faculty of Marine Science and Fisheries, Universitas Hasanuddin, Indonesia, for assistance with sample analysis.

\section{REFERENCES}

Ali H, Anshari KK, Prakash S. 2010. Haemotological abnormalities in an exotic caep, Hypopthalmichthys molitrix, infested by a fish louse, Argulus sp. Pollut Res 29: 593-595.

Alsarakibi M, Wadeh H, Li G. 2012 Freshwater abiotic components' impact on the viability of fish lice, Argulus sp., in Guangdong province, China. Parasitol Res 111 (1): 331-339. DOI: 10.1007/s00436-012-2844-7

Alsarakibi M, Wadeh H, Li G. 2014. Influence of environmental factors on Argulus japonicus occurrence of Guangdong province, China. Parasitol Res 113 (11): 4073-4083. DOI: 10.1007/s00436-014-40765.

Amriana, Sari DK, Sriwulan, Anshary H. 2021. Morphological and molecular description of Argulus indicus Weber, 1892 (Crustacea: Branchiura) found from striped snakehead fish (Channa striata) in Lake Towuti, Indonesia. AACL Bioflux 14 (3): 1373-1382.

Blaxhall PC, Daisley KW. 1973. Routine haematological methods for use with fish blood. J Fish Biol 5 (6): 771-781. DOI: 10.1111/j.10958649.1973.tb04510.x.

Bush AO, Lafferty KD, Lotz JM, Shostak AW. 1997. Parasitology meets ecology on its own terms: Margolis et al. Revisited. J Parasitol 83 (4): 575-583. DOI: $10.2307 / 3284227$.

Esteban MÁ, Cuesta A, Chaves-Pozo E, Meseguer J. 2015. Phagocytosis in teleosts. Implications of the new cells involved. Biol 4 (4): $907-$ 922. DOI: 10.3390/biology4040907.

Fazio F. 2019. Fish hematology analysis as an important tool of aquaculture: A review. Aquaculture 500: 237-242. DOI: 10.1016/j.aquaculture.2018.10.030.

Jones CM, Grutter AS. 2005. Parasitic isopods (Gnathia sp.) reduce haematocrit in captive blackeye thicklip (Labridae) on the Great Barrier Reef. J Fish Biol 66 (3): 860-864. DOI: 10.1111/j.10958649.2005.00640.x

Kar B, Mohanty J, Hemaprasanth KP, Sahoo PK. 2013. The immune response in rohu, Labeo rohita (Actinopterygii: Cyprinidae) to Argulus siamensis (Branchiura: Argulidae) infection: Kinetics of immune gene expression and innate immune response. Aquac Res 46 (6): 1-7. DOI: 10.1111/are.12279

Kar B, Moussa C, Mohapatra A, Mohanty J, Jayasankar P, Sahoo PK. 2016. Variation in susceptibility pattern of fish to Argulus siamensis: 
Do immune responses of host play a role? Vet Parasitol 221: 76-83. DOI: 10.1016/j.vetpar.2016.03.013

Kumar S, Kumar TS, Vidya R, Pandey PK. 2016. A prospective of epidemiological intervention in investigation and management of argulosis in aquaculture. Aquac Intl 6: 1-24. DOI: 10.1007/s10499016-0030-0

McPherson NJ, Norman RA, Hoyle AS, Bron JE, Taylor NGH. 2012. Stocking methods and parasite-induced reductions in capture: Modelling Argulus foliaceus in trout fisheries. J Theor Biol 312: 2233. DOI: $10.1016 /$ j.jtbi.2012.07.017

Mikheev VN, Pasternak AF, Valtonen ET. 2007. Host specificity of Argulus coregoni (Crustacea: Branchiura) increases at maturation.

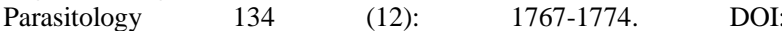
10.1017/S0031182007003125

Mikheev VN, Pasternak AF, Valtonen ET. 2015. Behavioural adaptations of argulid parasites (Crustacea: Branchiura) to major challenges in their life cycle. Parasites Vectors 8 (1): 1-10. DOI: 10.1186/s13071015-1005-0

Nasution SH, Sulastri S, Muchlisin ZA. 2015. Habitat characteristics of Lake Towuti, South Sulawesi, Indonesia - The home of endemic fishes. AACL Bioflux 8 (2): 213-223.

Neethling LAM, Avenant-Oldewage A. 2016. Branchiura - A compendium of the geographical distribution and a summary of their biology. Crustaceana 89 (11-12): $1243-1446$. DOI: $10.1163 / 15685403$ 00003597

Panjvini F, Abarghuei S, Khara H, Parashkoh HM. 2016. Parasitic infection alters haematology and immunity parameters of common carp, Cyprinus carpio, Linnaeus, 1758. J Parasit Dis 40 (4): 15401543. DOI: $10.1007 / \mathrm{s} 12639-015-0723-8$

Parida S, Mohapatra A, Mohanty J, Sahoo PK. 2018. Labeo rohita and Argulus siamensis infection: Host size, local inflammatory reaction and immunity modulate ectoparasite load on fish. Aquac Res 49: $757-$ 766. DOI: 10.1111/are.13506

Pekmezci GZ, Yardimci B, Bolukbas CS, Beyhan YE. 2011. Mortality due to heavy infestation of Argulus foliaceus (Linnaeus, 1758)
(Branchiura) in pond-reared carp, Cyprinus carpio L., 1758 (Pisces). Crustaceana 84: 553-557. DOI: 10.1163/001121611X574317.

Rocha MJS, Jerônimo GT, da Costa OTF, Malta JC de O, Martins ML, Maciel PO, Chagas EC. 2018. Changes in hematological and biochemical parameters of tambaqui (Colossoma macropomum) parasitized by metazoan species. Rev Bras Parasitol Vet 27 (4): 488494. DOI: 10.1590/S1984-296120180073

Sriwongpuk S. 2020. A new report of Argulus indicus (Crustacea: Branchiura) infestation in red tilapia (Oreochromis niloticus $\mathrm{x}$ Oreochromis mossambicus) in Thailand. Intl J Geomate 18 (67): 182187. DOI: $10.21660 / 2020.67 .5544$.

Stewart A, Jackson J, Barber I, Eizaguirre C, Paterson R, van West P, Williams C, Cable J. 2017. Hook, Line and Infection: A Guide to Culturing Parasites, Establishing Infections and Assessing Immune Responses in the Three-Spined Stickleback. Elsevier Ltd., United Kingdom.

Stewart A, Hunt R, Mitchell R, Muhawenimana V, Wilson CAME, Jackson JA, et al. 2018. The cost of infection: Argulus foliaceus and its impact on the swimming performance of the three-spined stickleback (Gasterosteus aculeatus). J Royal Soc Interface 15 (147): 20180571. DOI: 10.1098/rsif.2018.0571.

Tavares-Dias M, de Moraes FR. 2007. Leukocyte and thrombocyte reference values for channel catfish (Ictalurus punctatus Raf), with an assessment of morphologic, cytochemical, and ultrastructural features. Vet Clin Pathol 36 (1): 49-54. DOI: 10.1111/j.1939165x.2007.tb00181.x.

Walker PD, Russon IJ, Haond C, Van Der Velde G, Wendelaar-Bonga SE. 2011. Feeding in adult Argulus japonicus thiele, 1900 (maxillopoda, Branchiura), an ectoparasite on fish. Crustaceana 84 (3): 307-318. DOI: $10.1163 / 001121610 X 551$.

Weber M. 1892. Die süsswasser crustaceen des Indischen Archipels, nebst bemerkungen über die süsswasser fauna im allgemeinen. Zool Ergebnisse einer Reise Niederländisch Ost Indien 2: 528-571. [Germany]. 